UDC 669.295

\title{
THE REFINING OF TITANIUM BY CRUCIBLELESS ZONE MELTING METHOD
}

\author{
O.E. Kozhevnikov, M.M. Pylypenko, A.P. Shcherban, O.A. Datsenko, \\ V.M. Pelykh, V.D. Virych \\ National Science Center "Kharkov Institute of Physics and Technology”, Kharkiv, Ukraine \\ E-mail: kozhevnikov@kipt.kharkov.ua
}

The physical substantiation of titanium refining by crucibleless electron beam zone melting (ZM) method in vacuum was presented. Calculations of the equilibrium, limiting and effective distribution coefficients for impurity elements in the base metal were carried out. The refining of titanium was studied experimentally, and samples with a purity of $99.92 \mathrm{wt} . \%$ were received. The total content of impurities was reduced by a factor of 1.5 (from 0.12 to 0.08 wt. \%). The concentration of interstitial impurities was significantly reduced (oxygen - by 1.3; carbon - by 2; nitrogen - by 2.5 times). The structure and microhardness were investigated.

\section{INTRODUCTION}

The introduction and use of highly efficient fuel cycles at operating nuclear power plants with pressurized water reactors (WWER) has contributed to an increase in the operation duration of hull equipment and fuel elements, an increase in fuel burnup and steam content of the coolant. The resource and safety of nuclear reactors are determined by the characteristics of the materials used. Zirconium, hafnium, titanium, and also alloys based on them are widely used as structural and absorbing materials in thermal-neutron reactors.

Titanium and its alloys are used in pipes of heatexchange equipment, steam generators, feed pipes and collectors of transport systems, parts for internal saturation of pipe systems, and turbine blades. An alloy of titanium and $20 \%$ zirconium is a promising material for the manufacture of WWER vessels [1].

Titanium is necessary components to produce lowactivity alloys for nuclear energy of present and future. For example, the $\mathrm{V}-\mathrm{Ti}-\mathrm{Cr}$ alloys are the most promising as structural materials for fast reactors, possessing a low level of induced radioactivity and its rapid decline. The activation level of these alloys will be depending on impurity contents in alloys [2]

Due to the advancement in the field of aircraft and rocket production of titanium and its alloys are intensively developed. This is due to the combination of such valuable properties of titanium as low density, high specific strength, corrosion resistance, processability during pressure treatment and weldability, cold resistance, non-magnetic properties, and a number of other specific physical and mechanical characteristics.

The properties of titanium depend significantly on the content of impurities in the metal. Although the impurities increase the strength, at the same time, they sharply decrease the plasticity, and the most severe negative effect is caused by interstitial impurities. With the introduction of only $0.003 \%$ hydrogen, $0.02 \%$ nitrogen, or $0.7 \%$ oxygen, titanium completely loses its ability to plastic deformation and breaks down brittle. Carbon, iron, and silicon should also be included among the impurities harmful to the plasticity of titanium. Impurities such as nitrogen, oxygen and carbon raise the temperature of titanium allotropic transformation, while iron and silicon lower it. The resulting effect of impurities is expressed in the fact that technical titanium undergoes allotropic transformation not at a constant temperature $\left(882{ }^{\circ} \mathrm{C}\right)$, but in the temperature range $\left(865 \ldots 920^{\circ} \mathrm{C}\right)$ with the content of oxygen and nitrogen in the amount not exceeding $0.15 \mathrm{wt} . \%$. Under neutron irradiation of titanium alloys, embrittlement increases with an increase in the content of oxygen, nitrogen and hydrogen in the alloy. Therefore, the content of impurities, especially gases, in titanium and titanium alloys is strictly limited [3].

To increase the hydrogen resistance of titanium and its alloys for nuclear power, as well as to improve the characteristics of the NT-47 superconducting alloy for the international experimental thermonuclear reactor ITER, it is necessary to increase the requirements for the purity of raw materials through the use of spongy titanium of increased purity and/or iodide titanium. The iodide refining method allows to be purified titanium from nitrogen, hydrogen, oxygen, carbon and other impurities, using waste and production turnover as raw materials. Integral purity of iodide titanium can reach $99.9 \%$.

The purpose of this work was the computational and experimental studies of the process of titanium refining by crucibleless zone melting (ZM) in vacuum.

\section{PHYSICAL SUBSTANTIATION OF REFINING OF TITANIUM BY ZM METHOD}

\subsection{CALCULATION OF THE REFINING PROCESS USING THERMODYNAMIC PARAMETERS}

$\mathrm{ZM}$ is one of the most effective methods of metal refining. The method is based on the practical use of the phenomenon of different solubility of impurities in the solid and liquid phases of the main component [4].

The characteristic parameter of the ZM process is the distribution coefficient, which represents the ratio of the impurity concentration in the solid phase $C_{S}$ to the concentration in the melt $C_{L}$ : 


$$
k=C_{S} / C_{L} .
$$

The numerical value of the distribution coefficient depends on several factors: the disposition of the phase diagram formed by the main component and the impurity, the solidification conditions, the movement velocity of the molten zone, the intensity of mixing, etc. If $k<1$ the solidifying material becomes cleaner and the melt is saturated with the impurity.

There are differences between the concepts of the equilibrium distribution coefficient $k_{0}$ and effective distribution coefficient $k_{e}$. The equilibrium coefficient $k_{0}$ is usually determined from the "base-impurity" diagrams of the state with respect to the segments of the horizontal lines from the temperature axis to their intersection with the solidus and liquidus lines. It is assumed that $k_{0}$ does not depend on the impurity concentration in the main material and on the temperature. The exact calculation of $k_{0}$ on the basis of the phase diagrams is rather limited, since ZM process is used mainly for purification from small impurity concentrations, and the available phase diagrams are not accurate enough in this concentration range. Therefore, the calculation of the equilibrium coefficient should be considered only as an indicative estimate of the value. In practice, the value of $k_{0}$ can be achieved only if the zone moves very slowly.

When carrying out the ZM process, it is necessary that the rate of crystallization be greater than the diffusion rate of the impurity in the solid phase of the base material, but also does not exceed some optimal value. In this case, the moving crystallization front repels the dissolved impurity faster than it can evenly distribute in the melt, and an impurity-enriched region called the diffusion layer appears before the crystallization front. The width of the diffusion layer depends on the diffusion ability of the impurity, the viscosity of the melt, the nature of the fluid motion, the rate of crystallization.

Therefore, the main characteristic of the zone impurity separation is effective distribution coefficient $k_{e}$, which can be expressed by the Burton-Prim-Slichter formula [4]:

$$
k_{e}=\frac{k_{0}}{k_{0}+\left(1-k_{0}\right) e^{-\frac{v \delta}{D}},}
$$

where $v$ is zone speed; $\delta$ is the diffusion layer thickness, and $d$ is the diffusion coefficient of the impurity in the liquid.

Ratio $v \delta / D$ is called as the reduced rate of crystallization (it is dimensionless quantity). For most metals the value of the diffusion coefficient $D$ is $5 \cdot 10^{-5} \mathrm{~cm}^{2} / \mathrm{s}$ approximately. The width of the diffusion layer in the case of conservative melt mixing in the zone is $\delta \approx 0.01 \mathrm{~cm}$. Therefore, the ratio $\delta / D \approx 200 \mathrm{~s} / \mathrm{cm}$.

The values of the equilibrium coefficient $k_{0}$, determined from the phase diagrams by the solubility method, are quite reliable, since the values of the limiting solubility of the impurity and the point of invariant transformation were determined experimentally with good accuracy. However, it should be taken into account that in such calculations the values of the distribution coefficient $k$ are determined for significant concentrations of impurities in the base, but the parameter $k_{0}$ is usually a characteristic for impurities with a low content in the main component.

Therefore, when solving many tasks, it is used theoretical methods for calculating $k_{0}$, proceeding from thermodynamic constants, the equation of ideal solutions, etc. Assuming that an impurity with a low concentration forms a solid solution with a base, the value of $k_{0 i}$ for the $i$-th impurity can be determined from the special case of the Schroeder-Le Chatelier equation [5]:

$$
\ln \frac{C_{L_{i}}}{C_{S_{i}}}=-\frac{\Delta H}{R}\left(\frac{1}{T_{m}}-\frac{1}{T_{G i}}\right)=\lambda_{i},
$$

and then

$$
\frac{C_{L_{i}}}{C_{S_{i}}}=e^{\lambda_{i}} \text {, and } \quad k_{0 i}=\frac{1}{e^{\lambda_{i}}},
$$

where $C_{L i}$ and $C_{S i}$ are the concentrations of the $i$-th impurity in the liquid and solid phases of the main component; $\Delta H_{i}$ is the molar heat of fusion for the $i$-th impurity $(\mathrm{J} / \mathrm{mol}) ; R$ is the universal gas constant $(\mathrm{R}=8.314 \mathrm{~J} /(\mathrm{mol} \cdot \mathrm{K})) ; T_{m}$ is the melting temperature of the base substance $\left(T_{m}=1943 \mathrm{~K}\right) ; T_{G i}$ is the hypothetical value of the melting temperature of the $i$-th impurity, which is selected from the phase diagram view.

For phase diagrams forming a continuous series of solid solutions, diagrams of the peritectic type in the entire concentration range, as well as for impurities whose diagrams with the base metal are unknown, $T_{G i}$ corresponds to the melting point of the impurity element. In the case of phase diagrams with a number of eutectic and peritectic transformations, the value of $T_{G i}$ is chosen corresponding to the minimum transformation temperature of the eutectic or peritectic type [6].

Determining the values of $k_{0 i}$ according to relations (3), (4) it is possible to calculate the values of the effective distribution coefficient $k_{e i}$ according to formula (2).

It is known that a good degree of purification from volatile impurities is possible at high speeds of movement of the zone. Carrying out one or two passes at a speed of 16 or $8 \mathrm{~mm} / \mathrm{min}$ is sufficient for the metal impurities, which have a high saturated vapor pressure, to evaporate.

To remove refractory metal impurities and impurities with a low saturated vapor pressure $p_{0}$ at the melting point of titanium, it is necessary to carry out multiple zone recrystallization at a low rate, which makes it possible to gradually move impurities into the final part of the ingot, and thus reduce their concentration in the main length of the sample. The optimal speed of movement of the zone, at which it is possible to carry out effective refining with fewer passes, is $2 \mathrm{~mm} / \mathrm{min}$.

Table 1 represents the calculated values of the equilibrium $k_{0 i}$ and effective $k_{e i}$ distribution coefficients for typical metallic impurities, as well as the data on the limiting coefficient $k_{\text {Olim }}$ presented in [7]. 
Calculated values of equilibrium $k_{0 i}$ and effective $k_{e i}$ distribution coefficients for impurities in titanium

\begin{tabular}{|c|c|c|c|c|c|}
\hline Element & $T_{G i}, \mathrm{~K}$ & $\Delta H_{i}, \mathrm{~kJ} / \mathrm{mol}$ & $k_{0 i}$ & $k_{\text {Olim }}[7]$ & $k_{e i}$ \\
\hline $\mathrm{Ti}$ & 1943 & 18.8 & 1.0 & 1.0 & 1.0 \\
\hline $\mathrm{Al}$ & 933.5 & 10.75 & 0.49 & - & 0.65 \\
\hline $\mathrm{V}$ & 1878 & 17.5 & 0.96 & 0.8 & 0.98 \\
\hline $\mathrm{Fe}$ & 1358 & 13.8 & 0.69 & 0.3 & 0.81 \\
\hline $\mathrm{K}$ & 337 & 2.33 & 0.5 & - & 0.66 \\
\hline $\mathrm{Ca}$ & 1112 & 9.2 & 0.65 & - & 0.78 \\
\hline $\mathrm{Co}$ & 1293 & 15.48 & 0.62 & - & 0.76 \\
\hline $\mathrm{Si}$ & 1603 & 50.6 & 0.51 & - & 0.67 \\
\hline $\mathrm{Mn}$ & 1408 & 13.4 & 0.73 & 0.39 & 0.84 \\
\hline $\mathrm{Cu}$ & 1160 & 13.01 & 0.58 & 0.27 & 0.73 \\
\hline $\mathrm{Na}$ & 371 & 2.64 & 0.5 & - & 0.66 \\
\hline $\mathrm{Ni}$ & 1233 & 17.61 & 0.53 & 0.44 & 0.69 \\
\hline $\mathrm{Nb}$ & 2742 & 26.8 & 1.62 & 1.58 & 1.25 \\
\hline $\mathrm{S}$ & 386 & 1.23 & 0.74 & - & 0.84 \\
\hline $\mathrm{P}$ & 317 & 2.51 & 0.45 & - & 0.61 \\
\hline $\mathrm{Cr}$ & 1683 & 21 & 0.82 & 0.56 & 0.9 \\
\hline $\mathrm{Zr}$ & 1808 & 19.2 & 0.92 & 0.82 & 0.95 \\
\hline
\end{tabular}

An analysis of the state diagrams of double metal systems "titanium-impurity" [6] and the calculations of the equilibrium $k_{0 i}$ and effective $k_{e i}$ coefficients allow to conclude that during zone melting, due to the different solubility of impurities in the liquid and solid phases of the base metal, it is possible to carry out refining from most metallic impurities and some interstitial elements (Al, Fe, K, Ca, Co, Si, Mn, Cu, Na, Ni, S, P, Cr, Zr, $\mathrm{C}, \mathrm{H})$. An insignificant additions of these impurities lower the titanium melting point, and for them $k_{0 i}<1$.

The addition of some impurities $(\mathrm{Nb}, \mathrm{O}, \mathrm{N})$ increases the melting point of titanium, and for these impurities equilibrium coefficient $k_{0 i}>1$.

\subsection{CALCULATION OF LIMITING AND EQUILIBRIUM DISTRIBUTION COEFFICIENTS USING BINARY Ti-Me STATE DIAGRAMS}

In this work, the limiting $k_{\text {olim }}$ and equilibrium $k_{0 \mathrm{~B}}$ distribution coefficients of impurities in titanium were calculated from the experimentally constructed curves of the solidus and liquidus lines of state diagrams, and the dependence of the equilibrium distribution coefficients on concentration and temperature was studied in the range from the melting point of titanium to the temperature of the eutectic transformation. Below calculations are given for the Ti-Mn, Ti-Ni, Ti-Si, Ti-Co systems.

An analysis of the state diagrams [6] shows that the solidus and liquidus lines in the temperature range from the melting point of the pure component to the eutectic temperature are not right-lined, and therefore $k_{0 \mathrm{~B}}$ is a function of temperature $T$ and concentration $x$ in this interval according to the expression:

$$
k_{0 B}(\mathrm{~T}, \mathrm{x})=\mathrm{f}\left(x_{S B}(\mathrm{~T}) / x_{L B}(\mathrm{~T})\right) .
$$

The calculation of the distribution coefficients and their dependence on temperature and concentration is based on the method described in [7]. The method consists in the mathematical expression of the shape of the solidus and liquidus lines of state diagrams in the form of second-order polynomials:

$$
\begin{aligned}
& T_{S}=p_{S B} x_{S B}^{2}+q_{S B} x_{S B}+T_{M A}, \\
& T_{L}=p_{L B} x_{L B}^{2}+q_{S L} x_{L B}+T_{M A},
\end{aligned}
$$

where $T_{S}$ and $T_{L}$ are solidus and liquidus temperatures, ${ }^{\circ} \mathrm{C} ; T_{M A}-$ melting point of the main component $\mathrm{A},{ }^{\circ} \mathrm{C}$; $x_{S B}$ and $x_{L B}$ are the concentrations of component $\mathrm{B}$ on the solidus and liquidus lines, at. $\% ; p_{S B}, q_{S B}, p_{L B}, q_{L B}$ are the regression coefficients of the approximating equations.

Since an equilibrium coefficient of distribution is the isothermal ratio of concentration $x_{S B} / x_{L B}$, it should be observed equality:

$$
\Delta T_{S}=\Delta T_{L}=T_{M A}-T_{S}=T_{M A}-T_{L}=\Delta T_{M A} .
$$

Taking into account condition (8), from expressions (5) and (6) it is possible to derive the expression $k_{O B}$ as a function of the impurity concentration:

$$
k_{0 B}^{C}=\left(p_{L B} x_{L B}^{*}+q_{L B}\right) /\left(p_{S B} x_{S B}^{*}+q_{S B}\right) .
$$

In the same way, excluding concentrations, an expression can be obtained for the dependence of the equilibrium distribution coefficient on temperature:

$$
k_{O B}^{T}=\frac{p_{L B}\left( \pm \sqrt{q_{S B}^{2}-4 p_{S B} \Delta T_{M A}}-q_{S B}\right)}{p_{S B}\left( \pm \sqrt{q_{L B}^{2}-4 p_{L B}} \Delta T_{M A}-q_{L B}\right)} .
$$

The regression coefficients $p_{S B}, p_{L B}, q_{S B}, q_{L B}$ in expressions (6) and (7) were determined from the pairs of values $T_{S(i)}, x_{S B(i)}$ и $T_{L(j)}, x_{L B(j)}$ taken from the state diagrams by the method of least squares in mathematical package Maple.

The field of application of equations (6) and (7) is limited in the temperature range $\Delta T_{\mathrm{MA}}$ from the melting 
point $T_{\mathrm{MA}}$ of the main component to as close as possible to the eutectic temperature $T_{\mathrm{EA}}$. This interval (it is the region of solid solutions based on $\beta$-Ti) for each system is showed in Table 2.

The limiting distribution coefficient $k_{\text {olim } B}$ is determined by extrapolating the content of the second component to zero concentration $x_{\mathrm{B}} \rightarrow 0$ or at $T \rightarrow T_{\mathrm{MA}}$. This value can be obtained from the formula (9) at $x_{L B}=x_{S B}=0$ :

$$
k_{0 \lim B}=q_{L B} / q_{S B} .
$$

Table 2 represents the values of the regression coefficients of the approximating equations for the solidus and liquidus lines for the studied Ti-Me systems, the temperature range of applicability of the $\Delta T_{\mathrm{MA}}$ equations, and the calculated values of the limiting distribution coefficients $k_{\text {olimB }}$. For the Ti-Si and Ti-Co systems values of $k_{\text {olimB }}$ were not found in the literary source. For the systems Ti-Mn, Ti-Ni, the refined values of $k_{\text {olimB }}$ were obtained.

Table 2

The values of regression coefficients of equations for the solidus and liquidus lines in Ti-Me systems, temperature range of applicability of $\Delta T_{\mathrm{MA}}$ equations, and values of limiting coefficients $k_{\text {olimB }}$

\begin{tabular}{|c|c|c|c|c|c|c|c|}
\hline System & $p_{S}$ & $q_{S}$ & $p_{L}$ & $q_{L}$ & $\Delta T_{M A},{ }^{\circ} \mathrm{C}$ & $k_{\text {olim B }}$ & $k_{\text {olim B }}[7]$ \\
\hline Ti-Mn & 0.2094 & -22.2420 & -0.1404 & -5.6172 & 485 & 0.25 & 0.39 \\
\hline Ti-Ni & 2.0046 & -87.7359 & -0.5033 & -17.4277 & 520 & 0.2 & 0.44 \\
\hline Ti-Si & -0.3452 & -72.9805 & -0.9367 & -12.0652 & 353 & 0.17 & - \\
\hline Ti-Co & 2.8972 & -84.3990 & -0.9032 & -5.6579 & 600 & 0.07 & - \\
\hline
\end{tabular}

Table 3 represents the calculated values of $k_{0 B}^{C}$ and $k_{0 B}^{T}$, obtained from expressions (9) and (10), for the selected values of $\Delta T_{\mathrm{MA}}$. The calculations were performed in the Mathcad program.

Comparing with the data of the Table 2, there is a good agreement between the values $k_{0 B}^{C}$ and $k_{0 B}^{T}$ obtained from expressions (5) and (6) for the given identical values of $\Delta T_{\mathrm{MA}}$. This confirms the correctness of the calculated determination of the concentration and temperature dependence of the equilibrium distribution coefficients for these systems.

Table 3

The calculated values of the distribution coefficients $k_{0 B}^{C}$ and $k_{0 B}^{T}$ obtained for the selected values of $\Delta T_{\mathrm{MA}}$

\begin{tabular}{|c|c|c|c|c|c|c|c|c|c|c|c|}
\hline \multicolumn{3}{|c|}{ Ti-Si } & \multicolumn{3}{c|}{ Ti-Mn } & \multicolumn{3}{c|}{ Ti-Ni } & \multicolumn{3}{c|}{ Ti-Co } \\
\hline$k_{0 B}^{C}$ & $k_{0 B}^{T}$ & $\Delta T_{M A},{ }^{\circ} \mathrm{C}$ & $k_{0 B}^{C}$ & $k_{0 B}^{T}$ & $\Delta T_{M \mathrm{~A}},{ }^{\circ} \mathrm{C}$ & $k_{0 B}^{C}$ & $k_{0 B}^{T}$ & $\Delta T_{M A},{ }^{\circ} \mathrm{C}$ & $k_{0 B}^{C}$ & $k_{0 B}^{T}$ & $\Delta T_{M A},{ }^{\circ} \mathrm{C}$ \\
\hline 0.20 & 0.20 & 41.94 & 0.28 & 0.29 & 32.51 & 0.21 & 0.22 & 70.14 & 0.10 & 0.11 & 33.70 \\
\hline 0.21 & 0.22 & 64.52 & 0.32 & 0.33 & 72.66 & 0.23 & 0.23 & 101.36 & 0.12 & 0.14 & 72.22 \\
\hline 0.23 & 0.24 & 98.4 & 0.37 & 0.38 & 128.86 & 0.24 & 0.23 & 139.27 & 0.16 & 0.17 & 122.78 \\
\hline 0.25 & 0.26 & 146.8 & 0.42 & 0.42 & 183.46 & 0.26 & 0.26 & 192.79 & 0.17 & 0.18 & 166.11 \\
\hline 0.30 & 0.30 & 254.84 & 0.48 & 0.48 & 252.52 & 0.29 & 0.29 & 290.91 & 0.25 & 0.25 & 272.04 \\
\hline 0.32 & 0.32 & 306.45 & 0.56 & 0.56 & 344.05 & 0.30 & 0.30 & 333.28 & 0.31 & 0.32 & 377.97 \\
\hline
\end{tabular}

Fig. 1 shows the dependency graphs of equilibrium coefficients $k_{0 B}^{T}$ on $\Delta T_{\mathrm{MA}}$, plotted according to formula (10), for the systems Ti-Mn, Ti-Ni, Ti-Si, Ti-Co.

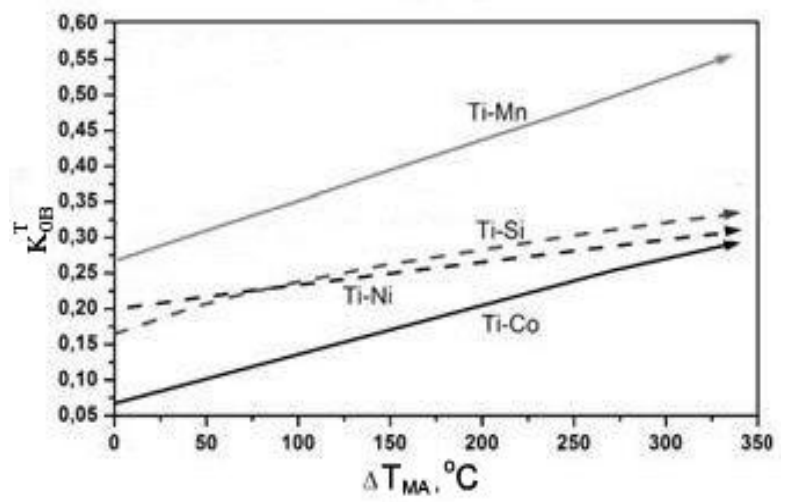

Fig. 1. Dependence of the equilibrium distribution coefficient $k_{0 B}^{T}$ on $\Delta T_{\mathrm{MA}}$ for systems $\mathrm{Ti}-\mathrm{Mn}, \mathrm{Ti}-\mathrm{Ni}, \mathrm{Ti}-\mathrm{Si}$, $\mathrm{Ti}-\mathrm{Co}$
The dependences were constructed using the Origin software package for numerical data analysis. An analysis of the plotted graphs showed that there is a linear dependence $k_{0 B}^{T}$ on $\Delta T_{\mathrm{MA}}$ in the selected temperature range for these systems.

\subsection{CALCULATION OF THE METAL REFINING PROCESS DUE TO THE EVAPORATION OF IMPURITIES}

When carrying out $\mathrm{ZM}$ in vacuum, in addition to purifying the material as a result of zonal separation of impurities, refining also occurs due to the evaporation of impurities with a high saturated vapor pressure at the melting point of the base material [8]. Among the existing methods for calculating the change in the concentration of an impurity element in the base metal due to evaporation, the most convenient is the method proposed in [9]. The reduced coefficient of evaporation of the $i$-th impurity $g_{i}$ (it is dimensionless value), which makes it possible to characterize the evaporation process, can be calculated by the formula: 


$$
g_{i}=\frac{2 \alpha_{i} \gamma_{i} p_{i}^{o} V l}{17.16 v r \sqrt{\frac{A_{i} T_{m}}{\eta_{i}}}}
$$

where $\alpha_{i}$ is the Langmuir coefficient; $p_{i}^{0}$ is the saturated vapor pressure at a melting temperature of basic material, Torr; $\gamma_{\mathrm{i}}$ is the activity coefficient of impurity; $A_{i}$ is the atomic weight in the condensed phase; $\eta_{i}$ is the number of atoms in a vapor molecule; $V=A_{b} / \rho_{b}$ atomic (molar) volume of the main component; $r$ is the radius of the molten zone, $l$ is the length of the zone, and $v$ is the velocity of the zone move.
Table 4 represents the calculated values of the reduced evaporation coefficient $g_{i}$, performed according to the formula (12). In the calculations, the values of the parameters were selected that are typical for the case of crucible-less zone melting of refractory metals with a low content of impurities: 1) the activity coefficient $\gamma_{i}=1$, since at the melting point of titanium, interactions between the $\mathrm{Ti}$ atoms and the atoms of impurity element with the formation of any stable bonds are not expected; 2) the evaporation of impurities occurs in the molecular mode in the form of monatomic molecules from a moderately stirred melt $\left(\alpha_{i}=1, \eta_{i}=1\right)$. The molar volume of titanium is $V_{T i}=10.6 \mathrm{~cm}^{3} / \mathrm{mol}$, the width of the molten zone is comparable to the radius of the rod $l \approx r \approx 0.4 \mathrm{~cm}$.

Table 4

The calculated values of the reduced evaporation coefficient $g_{i}$

\begin{tabular}{|c|c|c|c|c|c|c|c|c|c|c|c|c|c|c|c|c|c|}
\hline Element & $\mathrm{Ti}$ & $\mathrm{Al}$ & $\mathrm{V}$ & $\mathrm{Fe}$ & $\mathrm{K}$ & $\mathrm{Ca}$ & $\mathrm{Co}$ & $\mathrm{Si}$ & $\mathrm{Mn}$ & $\mathrm{Cu}$ & $\mathrm{Na}$ & $\mathrm{Ni}$ & $\mathrm{Nb}$ & $\mathrm{S}$ & $\mathrm{P}$ & $\mathrm{Cr}$ & $\mathrm{Zr}$ \\
\hline$P_{i}^{0}, \mathrm{~Pa}$ & 0,6 & 3192 & 0,12 & 53.2 & $2 \cdot 10^{6}$ & $5 \cdot 10^{5}$ & 1330 & 133 & 7980 & 266 & $9 \cdot 10^{8}$ & 2660 & $4 \cdot 10^{-7}$ & $2 \cdot 10^{14}$ & $2 \cdot 10^{18}$ & 106 & $1 \cdot 10^{-4}$ \\
\hline$g_{i}$ & 0.05 & 386 & 0.01 & 4.48 & $2 \cdot 10^{5}$ & $5 \cdot 10^{4}$ & 109 & 15,8 & 677 & 20.9 & $1 \cdot 10^{8}$ & 218 & $2 \cdot 10^{-8}$ & $2 \cdot 10^{13}$ & $3 \cdot 10^{17}$ & 9,3 & $3 \cdot 10^{-5}$ \\
\hline
\end{tabular}

Thus, when carrying out zone refining of titanium, one can expect a decrease in the concentration of a large amount of impurities due to evaporation (for example, $\mathrm{Al}, \mathrm{Ca}, \mathrm{Co}, \mathrm{Cr}, \mathrm{Cu}, \mathrm{Fe}, \mathrm{K}, \mathrm{Mn}, \mathrm{Na}, \mathrm{Ni}, \mathrm{P}, \mathrm{S}, \mathrm{Si}$ ). They are characterized at $1943 \mathrm{~K}$ by the values of the saturated vapor pressure $P^{0}{ }_{\mathrm{i}}>50 \mathrm{~Pa}$ and $g_{i}>4$. For titanium, the same parameters indices are $P^{0}=0.6 \mathrm{~Pa}$ and $g=0.05$.

\section{EXPERIMENTAL STUDY OF TITANIUM REFINING BY THE ZM METHOD \\ 2.1. RESEARCH METHODS AND MATERIALS}

The production of refined titanium samples was carried out using the crucibleless ZM method with electron-beam heating in a vacuum of $1 \cdot 10^{-4} \mathrm{~Pa}$. The advantages of this type of $\mathrm{ZM}$ include the ability to refine samples and grow single crystals of refractory metals and alloys, the absence of a crucible, the creation of a narrow heating region by focusing the electron beam, and a high specific power concentration. A detailed description of the zone melting unit for refining refractory metals is given in $[10,11]$.

The starting material used industrial titanium, obtained by refining iodide method (with integral purity of material 99.88 wt.\%).

The results of the impurity content in titanium materials were obtained by laser mass spectrometry. In the analysis, an EMAL-2 energy-mass analyzer was used, the limiting sensitivity of the analysis method for metal impurities was $\sim 10^{-5} \ldots 10^{-6}$ at. $\%$. The device was calibrated with certified LECO samples.

The visual inspection of thin sections and photographing of the grain structure were carried out using an MMP-4 microscope. The microhardness was measured on a PMT-3 microhardness tester at a load of $0.05 \mathrm{kgf}$. The value of the microhardness numbers was recorded by ten measurements; the measurement error did not exceed $5 \%$.

\subsection{RESULTS AND DISCUSSION}

The titanium refining process was carried out in several stages. At first, the initial billet of iodide Ti was heated for the purpose of degassing and melting at a high speed of zone passage (16 and $8 \mathrm{~mm} / \mathrm{min}$ ). Samples were obtained in the form of rods with a circular cross-section with a diameter of $8 \mathrm{~mm}$. In the second part of the experiments, zone recrystallization was carried out at a rate of $2 \mathrm{~mm} / \mathrm{min}$. All experiments were carried out in a vacuum of $1 \cdot 10^{-4} \mathrm{~Pa}$. Photos of samples are shown in Fig. 2.

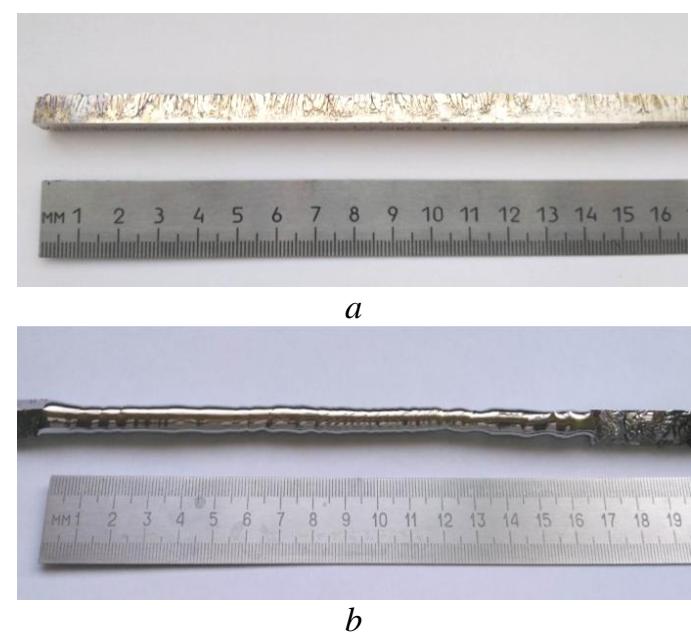

Fig. 2. View of the original billet of iodide titanium and ingot after $\mathrm{ZM}$

The results of the elemental composition analysis show a decrease in the content of a number of metal impurities in the refined ingots, which were removed during the simultaneous passage of the processes of zone recrystallization and evaporation. The concentration of aluminum was reduced by 1.7 ; iron - 1.3; calcium - 1.4; cobalt -4 ; manganese -7 ; nickel - 1.7; copper -4 ; chromium -1.7 ; phosphorus 1.4 times (Table 5). 
Elemental analysis results for titanium samples

\begin{tabular}{|c|c|c|c|c|c|c|c|c|c|c|c|c|}
\hline \multirow{2}{*}{ Titanium } & \multicolumn{10}{|c|}{ Concentration, wt.\% } \\
\cline { 2 - 12 } & $\mathrm{Ti}$ & $\mathrm{Al}$ & $\mathrm{V}$ & $\mathrm{Fe}$ & $\mathrm{Ca}$ & $\mathrm{Co}$ & $\mathrm{Si}$ & $\mathrm{Cu}$ & $\mathrm{Ni}$ & $\mathrm{Cr}$ & $\mathrm{S}$ & $\mathrm{Zr}$ \\
\hline Initial & 99.88 & 0.012 & $4.8 \cdot 10^{-4}$ & 0.03 & $1.7 \cdot 10^{-4}$ & $1 \cdot 10^{-4}$ & $6.2 \cdot 10^{-4}$ & $2 \cdot 10^{-3}$ & $3.3 \cdot 10^{-3}$ & $3 \cdot 10^{-3}$ & $3.5 \cdot 10^{-3}$ & $1.6 \cdot 10^{-3}$ \\
\hline After $\mathrm{ZM}$ & 99.92 & $7.6 \cdot 10^{-3}$ & $4.2 \cdot 10^{-4}$ & 0.022 & $1.2 \cdot 10^{-4}$ & $2.5 \cdot 10^{-5}$ & $5.2 \cdot 10^{-4}$ & $4.5 \cdot 10^{-4}$ & $1.9 \cdot 10^{-3}$ & $5 \cdot 10^{-5}$ & $2.9 \cdot 10^{-3}$ & $1.6 \cdot 10^{-3}$ \\
\hline
\end{tabular}

The refining of titanium from gas-forming impurities occurred at various stages of the experiment. Hydrogen left in the form of gaseous molecules $\left(\mathrm{H}_{2}, \mathrm{H}_{2} \mathrm{O}\right)$ during preliminary heating and $\mathrm{ZM}$ at a high rate. The carbon was vaporized as $\mathrm{CO}$ and $\mathrm{CO}_{2}$ molecules. Nitrogen evaporated in the form of $\mathrm{N}_{2}$ gas molecules during high-temperature heating and ZM. A decrease in the oxygen content occurred at the heating and $\mathrm{ZM}$ stages as a result of the formation of gaseous molecules $\left(\mathrm{CO}, \mathrm{CO}_{2}, \mathrm{H}_{2} \mathrm{O}\right)$. The refining also took place due to the displacement of metal carbides and oxides into the final part of the ingot at zone recrystallization.

In refined titanium samples, the concentration of oxygen was reduced by 1.3 (from 0.033 to $0.025 \mathrm{wt} . \%$ ), carbon -2 (from 0.01 to 0.0048 wt.\%), nitrogen -2.5 times (from 0.009 to 0.0035 wt. $\%$ ). The purity of the samples was characterized by a value of 99.92 wt.\% by titanium content. The total amount of impurities was reduced by a factor of 1.5 (from 0.12 to $0.08 \mathrm{wt} . \%$ ).

Fig. 3 shows photographs of the titanium sample microstructure before and after zone recrystallization.

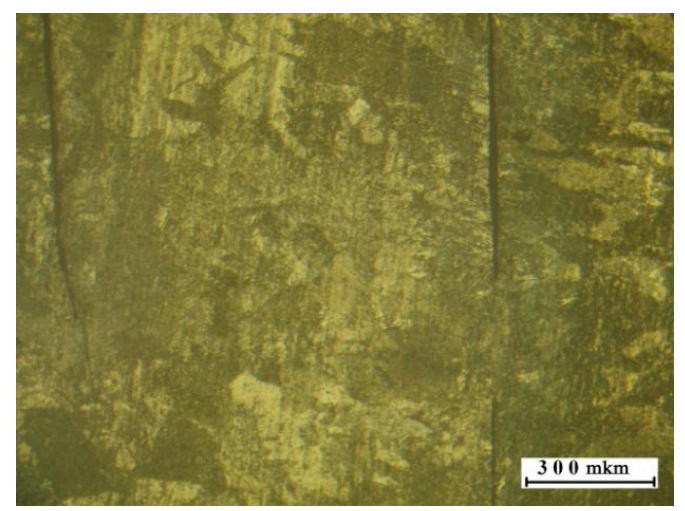

$a$

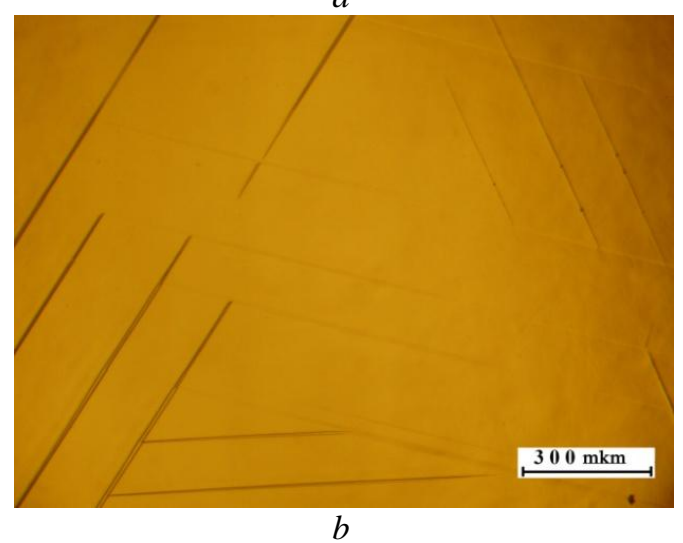

Fig. 3. Microstructure of samples of initial iodide titanium (a) and zone-melted titanium (b)

It is seen that the structure of zone-melted titanium (see Fig. 3,b) is more perfect. In the photographs you can see twins, as well as sliding lines along prismatic planes
$\{10 \overline{1} 0\}$. The grain boundaries are clean; the grain size reaches $5 \times 5 \times 7 \mathrm{~mm}$. The microhardness value for the samples of the initial iodide titanium varied in the range $H_{\mu}=1110 \ldots 1140 \mathrm{MPa}$. After the zone recrystallization, the grains of the material were aligned predominantly along the direction of the ZM (the deviation of the normal vector to the base plane from the direction of movement of the zone varied from 0 to $15^{\circ}$ ). The value of microhardness after melting with a speed of $16 \mathrm{~mm} / \mathrm{min}$ was equal to $H_{\mu}=1060 \ldots 1090 \mathrm{MPa}$. After zone recrystallization at a rate of $2 \mathrm{~mm} / \mathrm{min}$, the microhardness value decreased to $H_{\mu}=940 \ldots 970 \mathrm{MPa}$ due to a significant decrease in the content of interstitial impurities.

\section{CONCLUSIONS}

The physical substantiation of the process of titanium refining from metal impurities and interstitial impurities during $\mathrm{ZM}$ in vacuum is presented. Calculations of the equilibrium and effective distribution coefficients of impurities in titanium are carried out. The concentration and temperature dependences of the limiting coefficients have been determined for some titanium-impurity systems, including for $\mathrm{Ti}-\mathrm{Si}$ and $\mathrm{Ti}-\mathrm{Co}$, for which no data were found in the literature. Calculations of the metal refining process due to the evaporation of impurities have been performed.

To obtain refined titanium samples, we used a method consisting of preliminary heating and vacuum crucibleless zone melting with electron beam heating. The purity of the obtained samples was characterized by a value of 99.92 wt.\% by titanium content. The total amount of impurities was reduced by a factor of 1.5 (from 0.12 to $0.08 \mathrm{wt} . \%$ ). The concentration of interstitial impurities was significantly reduced (oxygen by 1.3 ; carbon -2 ; nitrogen -2.5 times). The microstructure and microhardness of titanium before and after refining have been investigated. For pure samples the value was equal to $H_{\mu}=940 \ldots 970 \mathrm{MPa}$ in comparison with the values for the initial material $H_{\mu}=1110 \ldots 1140 \mathrm{MPa}$.

\section{REFERENCES}

1. М.Л. Коцарь, С.А. Лавриков, В.И. Никонов, А.В. Александров и др. Высокочистые титан, цирконий и гафний в ядерной энергетике // Атомная энергия. 2011, т. 111, в. 2, с. 72-77.

2. M.M. Pylypenko, S.D. Lavrinenko. Pure vanadium and titanium for low activation alloys // Problems of Atomic Science and Technology. Series "Physics of Radiation Effect and Radiation Materials Science”. 2016, N 4, p. 49-53. 
3. О.П. Солонина, С.Г. Глазунов. Жаропрочные титановые сплавы. М.: «Металлургия», 1976, $448 \mathrm{c}$. $366 \mathrm{c}$

4. В. Пфанн. Зонная плавка. М.: «Мир», 1970,

5. Р. Лодиз, Р. Паркер. Рост монокристаллов. М.: «Мир», 1974, 540 с.

6. Диаграммы состояния двойных металлических систем: Справочник, т. 3, кн. 2 / Под ред. Н.П. Лякишева. М.: «Машиностроение», 2000, 448 с.

7. И. Бартел, Э. Буринг, К. Хайн, Л. Кухарж. Кристаллизация из расплавов: Справ. изд.: Пер. с нем. М.: «Металлургия», 1987, 320 с.

8. А.Н. Несмеянов. Давление пара химических элементов. М.: Изд-во АН СССР, 1961, 396 с.
9. Ш.И. Пейзулаев. Учет испарения примесей при зонной плавке // Изв. АН СССР. Сер. Неорг. материальь. 1967, т. 3, №9, с. 1523-1532.

10. П.Н. Вьюгов, О.Е. Кожевников, Т.Ю. Рудычева. Получение высокочистых образцов гафния методом бестигельной зонной плавки // Bonpocbl атомной науки и техники. Серия «Вакуум, чистые материаль, сверхпроводники». 2009, № 6, с. 19-24.

11. О.Е. Кожевников,

Н.Н. Пилипенко, В.Д. Вирич, Ю.С. Стадник, и др. Физическое обоснование и экспериментальное исследование рафинирования циркония методом зонной перекристаллизации // Bопросы атомной науки $u$ техники. Серия «Физика радиачионных повреждений и радиационное материаловедение». 2018, №5(117), с. 62-68.

Article received 04.06.2021

\title{
РАФИНИРОВАНИЕ ТИТАНА МЕТОДОМ БЕСТИГЕЛЬНОЙ ЗОННОЙ ПЛАВКИ
}

\author{
О.Е. Кожевников, Н.Н. Пилипенко, А.П. Щербань, О.А. Даценко, \\ В.Н. Пельх, В.Д. Вирич
}

Представлено физическое обоснование рафинирования титана методом бестигельной электроннолучевой зонной плавки в вакууме. Проведены расчеты равновесного, предельного и эффективного коэффициентов распределения для примесных элементов в основном металле. Экспериментально исследовано рафинирование титана, получены образцы чистотой 99,92 мас.\%. Суммарное содержание примесей снижено в 1,5 раза (с 0,12 до 0,08 мас.\%). Значительно уменьшена концентрация примесей внедрения (кислорода - в 1,3; углерода - в 2; азота - в 2,5 раза). Исследована структура и микротвердость.

\section{РАФІНУВАННЯ ТИТАНУ МЕТОДОМ БЕЗТИГЕЛЬНОГО ЗОННОГО ПЛАВЛЕННЯ \\ О.С. Кожевніков, М.М. Пилипенко, О.П. Щербань, О.А. Даценко, В.М. Пелих, В.Д. Вірич}

Представлено фізичне обгрунтування рафінування титану методом безтигельного електроннопроменевого зонного плавлення у вакуумі. Проведено розрахунки рівноважного, граничного та ефективного коефіцієнтів розподілу для домішкових елементів в основному металі. Експериментально досліджено рафінування титану, отримано зразки чистотою 99,92 мас.\%. Сумарний вміст домішок знижено в 1,5 рази (з 0,12 до 0,08 мас.\%). Значно зменшена концентрація домішок впровадження (кисню - в 1,3 ; вуглецю - в 2 ; азоту - в 2,5 рази). Досліджено структуру та мікротвердість. 